\section{Analisis Hukum Perlindungan Terhadap Anak Korban Kekerasan Fisik Dalam Rumah Tangga Menurut UU No.35 Tahun 2014 Tentang Perlindungan Anak}

oleh :

\begin{abstract}
Writing this journal will describe the
\end{abstract} backgrounds of children who are often be the victims of physical violence in household and how legal protection for children victims of physical violence in the household is reviewed from UUPA No. 35 of 2014 and what are the legal consequences for the perpetrators of violence against physical violence against children in the household and how to take legal measures to minimize physical violence against children in the household. The problems formulated in the formulation of the problem are How does the rule of Law no. 35 of 2014 provides protection for child victims of physical violence in the household, How is the criminal law policy to the protection of child victims of the crime of physical violence in the household. The approach used is normative juridical method. The normative juridical approach method is used to examine library materials which are primary data. Based on the data obtained, then it is analyzed to draw conclusions after being explained in detail based on available sources. And guarantee the basic rights of every child, provide facilities and infrastructure and protect, nurture and prosper children through the rights and obligations of parents. The criminal law policy regarding the protection of child victims from criminal acts of physical violence in household as referred to in Article $76 \mathrm{C}$, that the perpetrators of physical violence against children shall be sentenced to imprisonment for a maximum of 3 (three) years and 6 (six) years and / or a maximum fine of Rp.72,000,000.00 (seventy two million rupiah). How the non-penal law policy in minimizing the occurrence of child victims of physical violence in the household is more about preventing the occurrence of criminal acts, so that the main objective is to overcome the factors that are conducive to the occurrence of these crimes.
This conducive factor focuses on social problems or the conditions that can directly or indirectly cause or foster crime.

Keywords : Protection of Child, Victims of Physical Violence at Home, Child protection

\section{Abstrak}

Penulisan jurnal ini akan memaparkan latar belakang anak yang sering menjadi korban kekerasan fisik dalam rumah tangga dan bagaimana perlindungan hukum terhadap anak korban kekerasan fisik dalam rumah tangga ditinjau dari UUPA No. 35 tahun 2014 dan bagaimana konsekuensi hukum bagi pelaku kekerasan terhadap kekerasan fisik. anak dalam rumah tangga dan bagaimana upaya hukum dalam meminimalkan tindak kekerasan terhadap fisik anak dalam rumah tangga.Permasalahan yang dirumuskan dalam rumusan masalah adalah Bagaimana Negara Hukum UU No. 35 Tahun 2014 memberikan perlindungan bagi anak korban kekerasan fisik dalam rumah tangga.Bagaimana kebijakan hukum pidana terhadap perlindungan anak korban dari tindak pidana kekerasan fisik dalam rumah tangga.Metode pendekatan yang dilakukan adalah dengan menggunakan metode yuridis normatif.Metode pendekatan yuridis normatif digunakan untuk meneliti bahan pustaka yang merupakan data primer. Berdasarkan data yang diperoleh kemudian dianalisis untuk menarik kesimpulan setelah dijelaskan secara detail berdasarkan sumber yang ada.. Dan menjamin hak dasar setiap anak, menyediakan sarana dan prasarana serta melindungi, memelihara dan mensejahterakan anak melalui hak dan kewajiban orang tua.Kebijakan hukum pidana tentang perlindungan anak korban dari tindak pidana kekerasan fisik dalam rumah tangga sebagaimana dimaksud dalam Pasal 76C, bahwa pelaku kekerasan fisik terhadap anak dipidana dengan pidana penjara paling lama 3 (tiga) tahun 6 (enam) tahun.bulan dan / atau denda paling banyak Rp72.000.000,00 (tujuh puluh dua juta rupiah). Bagaimana kebijakan hukum nonpenal dalam meminimalisir terjadinya anak korban kekerasan fisik dalam rumah tangga lebih pada pencegahan terjadinya tindak pidana, sehingga tujuan utamanya adalah untuk mengatasi faktor-faktor yang kondusif bagi terjadinya tindak pidana tersebut.Faktor kondusif tersebut berpusat pada masalah atau kondisi sosial yang secara langsung maupun 
Media Komunikasi dan Informasi Hukum dan Masyarakat

tidak langsung dapat menyebabkan atau menumbuhkan kejahatan.

Kata Kunci : Perlindungan Terhadap Anak Korban Kekerasan Fisik, Rumah Tangga, Perlindungan Anak

\section{PENDAHULUAN}

\section{A.Latar Belakang Masalah}

Kehidupan berbangsa dan bernegara, anak merupakan calon generasi baru penerus bangsa yang diharapkan dapat menjadi penerus perjuangan cita-cita bangsa di masa yang akan datang. Begitu banyaknya fenomena kekerasan dan tindak pidana terhadap anak menjadi suatu sorotan keras dari berbagai kalangan. Hal ini dianggap sebagai suatu indikator buruknya instrumen hukum dan perlindungan anak. Berdasarkan UndangUndang Nomor 23 Tahun 2014 Pasal 20 tentang perlindungan anak, bahwa yang berkewajiban dan bertanggung-jawab terhadap penyelenggaraan perlindungan anak adalah negara, pemerintah, masyarakat, keluarga dan orang tua.

Penjelasan atas Undang-undang Nomor 35 Tahun 2014 tentang Perlindungan Anak juga mengamanatkan bahwa anak merupakan karunia dari Tuhan Yang Maha Esa yang harus dijaga dan dipelihara karena dalam dirinya terdapat harkat, martabat serta hak-hak asasi yang harus dijunjung tinggi. ${ }^{1}$

Menurut Pasal 1 ayat (1) dan ayat (2) Undang-undang Perlindungan Anak, dijelaskan bahwa :

Pasal 1 ayat (1) berbunyi :Anak adalah seseorang yang belum berusia 18

${ }^{1}$ Endang Sumiarni, 2003, Perlindungan Hukum Anak Dalam Hukum Pidana, Yogyakarta : Cetakan Pertama, Edisi Pertama, Universitas Atma Jaya, h. 722. (delapan belas) tahun, termasuk anak yangmasih dalam kandungan.

Pasal 1 ayat (2) berbunyi: Perlindungan anak adalah segala kegiatan untuk menjamin dan melindungi anak dan hakhaknya agar dapat hidup, tumbuh, berkembang, dan berpartisipasi, secara optimal sesuai dengan harkat dan martabat kemanusiaan, serta mendapat perlindungan dari kekerasan dan diskriminasi. $^{2}$

Hak-hak asasi yang harus dijunjung tinggi yang dimaksud dimuat dalam Undang Undang Dasar Negara Republik Indonesia tahun 1945 Pasal 28B ayat (2) bahwa anak memiliki 4 hak, yakni terdiri atas hak atas kelangsungan hidup, hak untuk tumbuh, hak untuk berkembang, serta hak atas perlindungan dari kekerasan dan diskriminasi". ${ }^{3}$

Berdasarkan UUPA No.35 Tahun 2014 orangtua berhak melakukan kewajiban terhadap anak

a. Mengasuh, memelihara, mendidik, dan meli ndungi Anak;

b. Menumbuhkembangkan Anak sesuai denga n kemampuan, bakat, dan minatnya;c. mencegah terjadinya perkawinan pada usia Anak; dand. memberikan pendidikan karakter dan penanaman nilai budipekerti pada Anak. (Pasal 26 ayat 1 Undang-undang Nomor 35 Tahun 2014 jo

${ }^{2}$ Departemen Kehakiman Republik Indonesia, 2002, Undang-undang Nomor 23 Tahun 2002 Tentang Perlindungan Anak, Jakarta : Pustaka Yustisia, h. 6

${ }^{3}$ Tim Redaksi Nuansa Aulia, 2009, Undang-Undang Dasar 1945 dan Amandemennya, Bandung : Cetakan V, Nuansa Aulia, Pasal 28B ayat (2). 
Media Komunikasi dan Informasi Hukum dan Masyarakat

Undang-undang Nomor 23 Tahun 2002 Tentang Perlindungan Anak). ${ }^{4}$

Perlindungan hukum atas anak dapat diartikan sebagai upaya perlindungan hukum terhadap hak asasi anak dan kepentingan yang berkaitan erat dengan kesejahteraan anak."Kesejahteraan Anak merupakan suatu pengaturan dan pemenuhan kebutuhan yang ditujukan untuk menjamin pertumbuhan dan perkembangan anak dengan wajar, baik secara rohani, jasmani maupun sosial". ${ }^{7}$

Pengertian tersebut tertuang dalam Undang-undang Nomor 4 Tahun 1979 tentang Kesejahteraan Anak Pasa1 1 ayat (1b).emenuhan kebutuhan anak yang dimaksudkan bertujuan untuk memberikan pemeliharaan, asuhan, perawatan serta perlindungan terhadap anak agar tumbuh dan berkembang dengan wajar baik secara rohani, jasmani maupun sosial.

Salah satu hak dalam mewujudkan pemenuhan kebutuhan anak ialah dengan diberikannya asuhan terhadap anak, selain hak untuk memperoleh asuhan, Undang-undang Nomor 35 Tahun 2014 tentang Perlindungan Anak juga menguraikan ada 4 (empat) macam hak anak menyangkut tentang hak asasi anak, yang terdiri atas:

1. Hak anak untuk hidup, tumbuh, berkembang, dan berpartisipasi serta mendapatkan perlindungan terhadap kekerasan dan diskriminasi (Pasal 4).

\footnotetext{
${ }^{4}$ Undang-undang Nomor 35 Tahun 2014 jo Undang-undang Nomor 23 Tahun 2002 Tentang Perlindungan Anak

${ }^{6}$ Waluyadi, 2009, Hukum Perlindungan Anak, Bandung : Cetakan Kesatu, Mandar Maju, 2009, h. 1

7 Endang Sumiarni dan Chandera Halim, 2000, Perlindungan Hukum Terhadap Anak Di Bidang Kesejahteraan, Cetakan Pertama/Edisi Pertama, Yogyakarta : Universitas Atma Jaya h. 15
}

2. Hak anak untuk dibesarkan dan diasuh oleh orang tuanya sendiri (Pasal 7 ayat (1)).

3. Hak anak untuk mendapatkan perlindungan dari perlakuan penelantaran selama anak tersebut berada dalam pengasuhan orangtua, wali, atau pihak lain manapun yang bertanggungjawab atas pengasuhan anak (Pasal 13 ayat (1)).

4. Hak anak untuk diasuh oleh orang tuanya sendiri, kecuali ada aturan hukum yang sah demi kepentingan terbaik bagi anak (Pasal 14 ayat (1)). Hak anak ini diatur dalam Undang-undang Nomor 35 Tahun 2014 tentang Perubahan Undang-undang Nomor 23 Tahun 2002 tentang Perlindungan Anak. ${ }^{8}$

Hak anak untuk diasuh oleh orang tuanya sendiri merupakan hak mutlak yang harus didapatkan oleh anak kandung selama orangtua kandungnya masih hidup.Orangtua memiliki kewajiban yang dibebankan oleh hukum untuk merawat dan menjaga anak agar dapat tumbuh serta berkembang dengan baik.Namun faktanya, tidak semua orangtua bertanggungjawab terhadap anak kandungnya.Bahkan ada ayah kandung yang mengabaikan hak-hak anak kandung.Kasus kekerasan anak dari orang tua kandungnya semakin banyak terjadi di Indonesia.

Kekerasan dalam rumah tangga (KDRT) merupakan fenomena sosial yang telah berlangsung lama dalam sebagian rumah tangga di dunia, termasuk di Indonesia.Jika selama ini kejadian tersebut nyaris tidak terdengar, hal itu lebih disebabkan adanya anggapan dalam masyarakat bahwa kekerasan dalam rumah tangga merupakan peristiwa

8 Undang-Undang Republik Indonesia Nomor 35 Tahun 2014 Tentang Perubahan Atas Undang-Undang Nomor 23 Tahun 2002 Tentang Perlindungan Anak, Pasal 14 ayat (1), 
Media Komunikasi dan Informasi Hukum dan Masyarakat

domestik yang tabu untuk dibicarakan secara terbuka. Kekerasan secara umum didiefinisikan sebagai suatu tindakan yang bertujuan untuk melukai seseorang atau merusak barang.Dalam hal ini segala bentuk ancaman, cemooh penghinaan, mengucapkan kata-kata kasar yang terus menerus juga diartikan sebagai bentuk tindakan kekerasan.Dengan demikian kekerasan diartikan sebagai penggunaan kekuatan fisik untuk melukai manusia atau untuk merusak barang, serta pula mencakup ancaman pemaksaan terhadap kekebasan individu."

Taylor, dkk menjelaskan kekerasan dalam rumah tangga adalah :

Tindak kekerasan yang dilakukan oleh satu anggota keluarga kepada anggota lainnya.Bentuk yang paling umum dari kekerasan rumah tangga adalah penganiayaan orang tua terhadap anak, penganiayaan suami terhadap istri, tetapi ada pula penganiayaan istri terhadap suami atau anak kepada orang tuannya.Dalam keluarga di mana istri dipukuli suaminya, anak juga terkena resiko dianiaya. Studi terhadap penganiayaan istri mengungkapkan bahwa hampir 25 persen dari anak mereka juga terkena penganiayaan fisik, dan separuhnya terkena penganiayaan verbal saat berada di kamar yang sama. ${ }^{10}$

Berdasarkan uraian di atas maka dapat dipahami bahwa kekerasan merupakan suatu perbuatan yang dilakukan orangtua terhadap anak berupa penganiayaan. Anak yang dianiaya mengalami banyak resiko, akibatnya anak menunjukkan stres kronis, termasuk kesulitan di sekolah dan masalah kosentrasi, mungkin yang

9 Purniaanti, 1996, Apa dan Bagaimana Kekerasan Dalam Keluarga, Jakarta : Kongres Wanita Indonesia (KOWANI).

${ }^{10}$ Taylor, Shelley E., Peplau Leitia Anne \& Sears, 2009, Psikologi Sosial, Jakarta : Edisi 12, Kencana, 2009, h. 24 paling buruk, mereka tumbuh menjadi penganiaya pula.

Kekerasan dalam rumah tangga terhadap anak sering terjadi, sebagai contoh kasus yang dialami oleh anak dalam kasus di Kota Medan adalah Kasus Syubhan, ayah yang tega mematahkan kaki anaknya berbuntut panjang. Istri Syubhan, Selvi dan anak-anaknya meminta bantuan pihak kepolisian dalam penyelesaian kelanjutan biduk rumah tangganya tanggal 28-2-2018. Dalam hal ini pihak Kepolisian Medan Kota melakukan penahanan terhadap Syubhan."Bersama Kapolsek dan penyidik perempuan anak, dilakukan konseling soal anak yang menjadi korban kekerasaan ayah kandungnya.Konselingnya di ruang Kapolsek," kata AKP Martualesi Sitepu selaku Kepala Unit Reserse Kriminal Polsek Medan Kota, Minggu (28/2/2018). Polsek Medan Kota AKP Martualesi, problema yang terjadi di rumah tangga Syubhan dan Selvi ini sudah berlangsung dua tahun belakangan. Faktor ekonomi dan ketidakharmonisan yang menjadi permasalahan."Dari keluhan istri pelaku, bahwa mereka kesulitan ekonomi karena pendapatan pas-pasan.Tapi suaminya itu (Syubhan) tidak bisa diharapakan.Malah dia juga pernah tertangkap tangan baru saja nyabu oleh istrinya," ungkap Martualesi.Diketahui selama ini Syubhan hanya bekerja sebagai penarik becak motor.Sedangkan Selvi bekerja sebagai juru masak yang bergaji Rp 50 ribu per harinya.Dan saat ini merela telah dikaruniai empat orang anak. Pada konseling ini, Kapolsek Medan Kota, Kompol Ronald Sipayung bilang kepada Selvi jika memerlukan bantuan di kemudian hari, jangan sungkan datang ke Polsek Medan Kota. Di akhir konseling Kapolsek Medan Kota juga memberikan bantuan pengobatan terhadap korban yang masih menjalani rawat 
Media Komunikasi dan Informasi Hukum dan Masyarakat

jalan dan setiap harinya harus diurut di dukun patah.

Dari fakta yang telah terjadi seperti dijelaskan dalam contoh kasus tersebut, realitas kehidupan anak di Indonesia masih belum menggembirakan. Nasib mereka belum seindah verbal yang memposisikan anak bernilai dan penerus masa depan bangsa. Pada tataran hukum, hak-hak yang diberikan hukum kepada anak belum sepenuhnya ditegakkan.Belum lagi berbagai permasalahan terjadinya kekerasan fisik terhadap anak atas perlakuan orangtuanya.

Dengan demikian, yang dimaksud dengan perlindungan hukum terhadap anak korban kekerasan dari orangtua kandung yang melakukan tindak kekerasan terhadap anak kandung adalah akibat dari suatu perbuatan atau reaksi dari pihak lain atas suatu perbuatan ayah kandung yang memiliki hubungan darah. Ayah kandung telah terbukti melakukan pemukulan terhadap seorang anak kandung yang telah memenuhi semua unsur delik seperti yang telah ditentukan di dalam rumusan delik yang bersangkutan. Tanpa orang-orang tersebut tetap dapat dihukum karena tindakan yang dilakukan oleh pelaku terhadap korban merupakan perbuatan yang mengakibatkan tidak terpenuhinya hak anak kandung baik secara jasmani, rohani maupun sosial.Hal tersebut disebabkan karena ayah kandung telah mengabaikan tanggungjawabnya dan terbukti telah melakukan tindak kekerasan fisik terhadap anak kandungnya.

Berkaitan dengan kondisi objektif saat ini tentang banyaknya tindak kekerasan fisik terhadap anak dalam keluarga dan relevansinya dengan UUPA No.35 Tahun 2014 pasal 1 dijelaskan bahwa :

1. Ayat 1 bahwa Anak adalah seseorang yang belum berusia 18 (delapan belas) tahun, termasuk anak yang masih dalam kandungan.

2. Ayat 2 bahwa perlindungan anak adalah segala kegiatan untuk menjamin dan melindungi anak dan hak-haknya agar dapat hidup, tumbuh, berkembang dan berpaprtisipasi secara optimal sesuai dengan harkat dan martabat kemanusiaan, serta mendapat perlindungan dari kekerasan.

3. Pasal 1 ayat 16 menjelaskan bahwa kekerasan adalah suatu perbuatan terhadap anak yang berakibat timbulnya kesengasaraan atau penderitaan secara fisik, psikis, seksual dan atau penelantaran, termasuk ancaman untuk melakukan perbuatan,pemaksaan atau perampasan kemerdekaan secara melawan hukum.

Kekerasan yang dimaksudkan dalam penelitian ini adalah kekerasan fisik yang dilakukan oleh orangtua terhadap anak sehingga melukai atau membuat anak cedera secara fisik.Kondisi objektif di lapangan ditemukan banyak anak korban dari kekerasan fisik dalam rumah tangga.

Berdasarkan permasalahan yang telah dijabarkan, maka penulis tertarik untuk menyusun tesis dengan judul :Analisis Hukum Perlindungan Terhadap Anak Korban Dari Kekerasan fisik Rumah Tangga Menurut UUPA No.35 Tahun 2014.

\section{B. Rumusan Masalah}

Berdasarkan latar belakang masalah yang telah dijabarkan, maka penulis merumuskan rumusan masalah :

1. Bagaimana aturan hukum UUPA No.35 Tahun 2014 memberikan perlindungan 
Media Komunikasi dan Informasi Hukum dan Masyarakat

anak korban kekerasan fisik dalam rumah tangga?

2. Bagaimana kebijakan hukum pidana terhadap perlindungan anak korban dari tindak pidana kekerasan fisik dalam rumah tangga?

\section{Metode Penelitian}

Penelitian ini menggunakan metode penelitian hukum normatif yang meneliti norma hukum, sinkronisasi hukum, asas hukum, dan sampai pada tujuan hukum itu sendiri serta efektif atau tidaknya hukum itu. Penelitian menganilisis norma hukum dan efektivitas perlindungan anak korban kekerasan fisik dalam rumah tangga. Adapun teori yang digunakan dalam penelitian ini adalah teorin perundangundangan. Terkait segala bentuk peraturan perundang-undangan yang bersinggungan dengan perlindungan anak, diantaranya : Undang-undang No 35 Tahun 2014 twntang perlindangan terhadap anak, Undang-undang No 4 Tahun 1979 Tentang kesejahteraan Anak, Kitab Undang-undang Hukum Perdata, Kitab Undang-undang hukum pidana. Bahan hukum yang digunakan penulis dalam peniltian ini adalah Bahan hukum primer yaitu segala peraturan perundang-undangan yang berkaitan dengan perlidungan anak. Bahan hukum primer buku,media cetak. Kemudian seluruh bahan hukum dianalisis hingga sampai penarikan kesimpulan dengan bentuk deskripsi.
A. Aturan Hukum UUPA no. 35 tahun2014 memberikan perlindungan terhadap anak korban kekerasan fisik dalam rumah tangga

Negara-negara Anggota PBB termasuk Indonesia sebagai Negara yang telah menandatangani perjanjian-perjanjian dan konvensi-konvensi internasional, bertanggung jawab untuk mematuhi perjanjian, protocol dan konvensi-konvensi yang telah diratifikasi dalam wilayah nasional mereka. Konvensi Hak-Hak Anak Perserikatan Bangsa-Bangsa (bahasa Inggris: United Nations Convention On The Rights of The Child ) adalah sebuah konvensi internasional yang mengatur hak-hak sipil, politik, ekonomi, sosial, dan kultural anak-anak. Oleh sebab itu, pemerintah ${ }^{1}$ memikul seluruh tanggung jawab untuk memngimplementasikan kewajiban-kewajiban internssional ini, serta mandat kepemimpinan dalam melaksanakan peraturan dan mekanisme yang diperlukan untuk mewujudkan kewajiban tersebut. Dan, sebagai bentuk nyata dari komitmen Pemerintah Indonesia dalam perlindungan anak telah disahkan Undang-undang Nomor 23 Tahun 2002 yang mana sekarang sudah terjadi perubahan atas UU tersebut menjadi UndangUndang NO 35 tahun 2014 Tentang Perlindungan Anak.

Dilihat dari sosial sebagai kehormatan harkat martabat keluarga tergantung pada sikap dan perilaku anak untuk berpresiasi, dan budaya anak merupakan harta dan kekayaan yang harus dijaga dan sekaligus merupakan lambing kesuburan sebuah keluarga, dari politik anak merupakan penerus suku, bangsa, dan ekonomi dilihat dari segi hukum, anak

\footnotetext{
${ }^{1}$ Dirjosisworo, S.,2005, Sosio kriminologi Amalan IImuIlmu Sosial Dalam Studi Kejahatan, Bandung, Sinar Baru, h. 87
} 
Media Komunikasi dan Informasi Hukum dan Masyarakat

mempunyai posisi dan kedudukan strategis di depan hukum, tidak saja sebagai penerus dan ahli waris keluarga tetapi sebagai bagian dari subyek hukum dengan segala pemenuhan kebutuhan untuk anak yang mendapat jaminan hukum, Jhon Lock mengemukakan bahwa anak merupakan paribadi yang masih bersih dan peka terhadap ransangan-ransangan yang berasal dari lingkungannya. Anak juga tidaklah sama dengan orang dewasa, anak mempunyai kecendrungan untuk menyimpang dari hukum dan ketertiban yangdisebabkan oleh keterbatasan pengetahuan dan pengertian terhadap realita kehidupan, anak-anak lebih mudah belajar dengan contoh-contoh yang diterimanya dari aturan-aturan bersifat memaksa.

Anak didalam masa pertumbuhan secara fisik dan mental membutuhkan perawatan, perlindungan, khusus serta perlindungan sebelum maupun sesudah lahir.Disamping itu, juga patut diakui bahwa keluarga merupakan limgkungan alami bagi pertumbuhan dan kesejahteraan anak.Untuk perkembangan kepribadiannya maka membutuhkan lingkungan keluarga yang penuih kasih sayang.Sobur juga mengartikan anak sebagai orang atau manusia yang mempunyai pikiran, sikap, perasaan, dan minat berbeda denga orang dewasa dengan segala keterbatasan.

Defenisi anak menurut Haditono $\left(^{2}\right.$ dalam damayanti, 1992), anak adalah makhluk yang membutuhkan kasih sayang, pemeliharaan, dan tempat bagi perkembangannya.Selain itu anak merupakan bagian dari keluarga, dan keluarga memberi kesempatan kepada anak untuk belajar tingkah

\footnotetext{
2 Moerti Hadiati Soeroso, 2010, Kekerasan Dalam Rumah Tangga Dalam Persepektif Yuridis Viktimologis, Jakarta : Sinar Grafika,. h.1
}

laku yang penting untuk perkembangan yang cukup baik dalam kehidupan bersama.Pengertian anak juga mencakup masa anak itu ada, hal ini untuk menghindari kerancuan terhadap penegertian aanak dalam hubungannya dengan orang tua dan pengertian anak itu sendiri setelah menjadi orang tua. Anak merupakan makhluk sosial yang membutuhkan pemeliharaan, kasih sayang dan tempat bagin perkembangannya, dan anak juga mempunyai perasaan, pikiran, kehendak tersendiri yang kesemuanya itu merupakan totalitas psikis dan sifat-sifat struktur berlainan pada tiap-tiap fase perkembangan pada masa kanak-kanak.

Begitu banyaknya fenomena kekerasan dan tindak pidana terhadap anak menjadi suatu sorotan keras dari berbagai kalangan. Hal ini dianggap sebagai suatu indikator buruknya instrumen hukum dan perlindungan anak. Berdasarkan Pasal 1 angka 2 Undang-Undang Perlindungan Anak No 35 Tahun 2014 "Perlindungan anak adalah segala kegiatan untuk menjamin dan melindungi anak dan hak-haknya agar dapat hidup, tumbuh, berkembang, dan berpartisipasi, secara optimal sesuai dengan harkat dan martabat kemanusiaan, serta mendapat perlindungan dari kekerasaan dan diskriminasi".

Perlindungan anak bertujuan untuk menjamin terpenuhinya hak-hak anak agar dapat hidup, tumbuh, berkembang, dan berpartisipasi secara optimal sesuai dengan harkat dan martabat kemanusiaan, serta mendapat perlindungan dari kekerasan dan diskriminasi, demi terwujudnya anak Indonesia yang berkualitas, berakhlak mulia, dan sejahtera. Negara,Pemerintah wajib menghormati pemenuhan hak anak Seperti 
Media Komunikasi dan Informasi Hukum dan Masyarakat

yang tercantum dalam Undang-Undang No 35 Tahun 2014 dalam pasal 21 ayat $1 \mathrm{~s} / \mathrm{d} 6$ :

1. Negara,Pemerintah, dan Pemerintah Daerah berkewajiban dan bertanggung jawab menghormati pemenuhan Hak Anak tanpa membedakan

suku,agama,ras,golongan,jenis

kelamin,etnik,budaya dan bahasa, status hukum, urutan kelahiran,dan kondisi fisik dan/atau mental

2. Untuk menjamin pemenuhan Hak Anak sebagaimana dimaksud pada ayat (1),Negara berkewajiban untuk memenuhi,melindungi, dan menghormati Hak Anak.

3. Untuk menjamin pemenuhan Hak Anak sebagaimana dimaksud pada ayat (1), Pemerintah berkewajiban dan bertanggung jawab dalam merumuskan dan melaksanakan kebijakan di bidang penyelanggaraan Perlindungan Anak

4. Untuk menjamin pemenuhan Hak Anak dan melaksanakan kebijakan sebagaimana dimaksud pada ayat (3), Pemerintah Daerah berkewajiban dan bertanggung jawab untuk melaksanakan dan mendukung kebijakan Nasional dalam penyelenggaraan Perlindungan Anak di daerah.

5. Kebijakan sebagaimana dimaksud pada ayat (4) daapat diwujudkan melalui upaya daerah membangun kabupaten/kota layak Anak

6. Ketentuan lebih lanjut mengeni kebijakan kabupaten/kota layak Anak sebagaimana dimaksud pada ayat (5) diatur dalam Peraturan Presiden.
Menurut Maidin Gultom, prinsip-prinsip

perkindungan anak anatar lain,yaitu: ${ }^{3}$

a. Anak tidak dapat berjuang sendiri

Salah satu prinsip yang digunakan dalam perlindungan anak adalah Anak itu modal utama kelangsungan hidup manusia, bangsa, dan keluarga, untuk itu hak-haknya anak harus dilindungi.Anak tidak dapat melindungi sendiri hak-haknya, banyak pihak yang mempengaruhi kehidupannya oleh karena itu, Negara dan masyarakat berkepentingan untuk mengusahajan perlindungan hak-hak anak.

b. Kepentingan terbaik anak ( the best interest of the child )

Agar perlindungan anak dapat diselenggarakan dengan baik, dianut prinsip yang menyatakan bahwa kepentingan terbaik anak harus dipandang sebagai of paramount importence (memperoleh prioritas tertinggi) dalam setiap keputusan yang menyangkut anak. Tanpa prinsip ini perjuangan untuk melindungi anak akan mengalami hambatan. Prinsip the best interest of the child digunakan karena faktor usia dan pengetahuannya yang rendah. Jika prinsip ini diabaikan, maka masyarakat menciptakan monster-monster yang lebih buruk kemudian hari

c. Ancaman daur kehidupan ( life circle approach )

Perlindungan anak mengacu pada pemahaman bahwa perlindungan anak harus dimulai sejak dini dan tertus menerus. Janin yang berada dalam kandungan perlu

\footnotetext{
${ }^{3}$ Abdul Hakim G. 1996, Nusantara, Hukum dan hak-hak anak, Prospek Perlindungan Anak, CV. Rajawali, Jakarta,h.104

Schafer, Stephen,2008. The Victim and His Criminal, New York: Randam House,
} 
Media Komunikasi dan Informasi Hukum dan Masyarakat

dilindungi dengan gizi,termasuk yodium dan kalsium yang baik melalui ibunya. Jika ia telah lahir, maka diperlukan air susu ibu dan pelayanan kesehatan primer dengan memberikan pelayanan imunisasi dan lainlain, sehingga terbatas dari berbagai kemungkinan cacat dan penyakit.

d. Lintas sektoral

Nasib anak tergantung dari berbagai faktor makro maupun mikro yang langsung maupun tidak langsung. Kemiskinan, perencanaan kota dan segala penggusuran, system pendidikan yang menekankan hapalan dan bahan-bahan yang tidak relevan, komunitas yang penuh dengan ketidakadilan, dan sebagainya tidak dapat ditangani oleh sector, terlebih keluarga atau anak itu sendiri. Perlindungan terhadap anak adalah perjuangan yang membuuhkan sumbangan semua orang di semua tingkatan. $^{4}$

Terbentuknya Undang-undang No 35 Tahun 2014 Tentang Perlindungan Anak ini dibentuk mempunyai tujuan, yakni untuk menjamin terpenuhinya kebutuhan anak agar dapat hidup, tumbuh, berkembang dan bepastisipasi secara optimal sesuai dengan harkat dan martabat kemanusiaan, serta mendapat perlindungan dari kekerasan dan diskriminasi, demi terwujudnya anak Indonesia yang berkualitas, berakhlak mulia, dan sejahtera. Seseorang manusia mempunyai hak asasi manusia yang telah diundangkan oleh Negara kepada warga negaranya, berarti seseorang manusia mempunyai hak asasi sedari sejak dilahirkan, begitupun dengan anak, anak mempunyai hak yang sedikit berbeda dengan orang yang sudah dewasa menurut Undang-Undang yang berlaku di Indonesia ini. Setiap anak selama dalam pengasuhan orang tuanya yang bertanggung jawab atas pengasuhan, layak mendapatkan perlindungan dan perlakuan yang sah menurut peraturan yang berlaku di Negara ini. Masalah perlindungan hukum bagi anak-anak merupakan salah satu sisi pendekatan untuk melindungi anak-anak, oleh sebab itu masalahnya tidak semata-mata bisa didekati secara yuridis, tetapi perlu pendekatan yang lebih luas, yaitu ekonomi,sosial dan budaya.

\section{Keberadaan Undang-Undang Nomor 35} Tahun 2014 tentang Perubahan Atas UndangUndang Nomor 23 Tahun 2002 tentang Perlindungan Anak tidak hanya memberikan perlindungan sebagaimana yang diatur tetapi juga mempertegas perlunya pemberatan sanksi pidana dan denda bagi pelaku kejahatan terhadap anak terutama kepada kejahatan seksual yang bertujuan untuk memberikan efek jera, serta mendorong adanya langkah konkrit untuk memulihkan kembali fisik, psikis dan sosial anak.

Hal tersebut perlu dilakukan untuk mengantisipasi anak (korban kejahatan) dikemudian hari tidak menjadi pelaku kejahatan yang sama. Karena berdasarkan fakta yang terungkap pada saat pelaku kejahatan terhadap anak (terutama pelaku kejahatan seksual) diperiksa di persidangan, pada kenyataannya ada beberapa pelaku yang mengaku bahwa pernah mengalami tindakan pelecehan ${ }^{5}$ seksual ketika pelaku masih berusia anak. Oleh karenanya, keberadaan undang-undang ini semoga menjadi harapan baru dalam melakukan perlindungan terhadap anak.Berikut

Undang-undang No 35 Tahun 2014 Tentang Perubahan Atas Undang-Undang Nomor 23 Tahun 2002 Tentang Perlindungan Anak, 
Media Komunikasi dan Informasi Hukum dan Masyarakat

adalah beberapa poin penting dalam undnagundang tersebut.

Pasal 1

Dalam Undang-Undang ini yang dimaksud dengan:

1. Anak adalah seseorang yang belum berusia 18 (delapan belas) tahun, termasuk anak yang masih dalam kandungan.

2. Perlindungan Anak adalah segala kegiatan untuk menjamin dan melindungi Anak dan hak-haknya agar dapat hidup, tumbuh, berkembang, dan berpartisipasi secara optimal sesuai dengan harkat dan martabat kemanusiaan, serta mendapat perlindungan dari kekerasan dan diskriminasi.

Pasal 76E UU

Setiap Orang dilarang melakukan Kekerasan atau ancaman Kekerasan, memaksa, melakukan tipu muslihat, melakukan serangkaian kebohongan, atau membujuk Anak untuk melakukan atau membiarkan dilakukan perbuatan cabul.

\section{Pasal 82}

(1) Setiap orang yang melanggar ketentuan sebagaimana dimaksud dalam Pasal $76 \mathrm{E}$ dipidana dengan pidana penjara paling singkat 5 (lima) tahun dan paling lama 15 (lima belas) tahun dan denda paling banyak Rp5.000.000.000,00 (lima miliar rupiah).

(2) Dalam hal tindak pidana sebagaimana dimaksud pada ayat (1) dilakukan oleh Orang Tua, Wali, pengasuh Anak, pendidik, atau tenaga kependidikan, maka pidananya ditambah 1/3 (sepertiga) dari ancaman pidana sebagaimana dimaksud pada ayat (1). ${ }^{5}$ pasal 82
Undang-undang Nomor 35 Tahun 2014 tentang Perubahan Undang-undang Nomor 23 Tahun 2002 tentang Perlindungan Anak Pasal 14 ayat (1) bahwa anak berhak untuk diasuh oleh orangtuanya sendiri, kecuali ada aturan hukum yang sah demi kepentingan terbaik bagi anak.

Dengan adanya Undang-Undang No 35 Tahun 2014 Tentang Perlindungan Anak dapat membantu untuk mengatasi maraknya tindakan kekerasan terhadap anak di Indonesia. Upaya lain yang dapat dilakukan untuk mengurangi terjadinya kekerasan pada anak yaitu dengan meberikan penyuluhan berupa nasehat kepada orangtua tentang pentingnya merawat anak baik dalam menjalani kehidupan maupun dalam bidabg agama. Perlindungan terhadap anak korban kekerasan dalam rumah tangga dapat dilakukan melalui hukum, baik hukum administrasi perdata maupun pidana.

\section{B. Kebijakan Hukum Pidana Terhadap} Perlindungan Anak Korban Dari Tindak Pidana Kekerasan Fisik Dalam Rumah Tangga

Perlindungan anak adalah segala usaha yang dilakukan untuk menciptakan kondisi agar setiap anak dapat melaksanakan hak dan kewajibannya demi perkembangan dan pertumbuhan anak secara wajar baik fisik, mental, dan sosial.Perlindungan anak merupakan perwujudan adanya keadilan dalam suatu masyarakat, dengan demikian perlindungan anak diusahakan dalam berbagai bidang kehidupan bernegara dan bermasyarakat.Kegiatan perlindungan anak membawa akibat hukum, baik dalam kaitannya dengan hukum tertulis maupun hukum tidak tertulis.Hukum merupakan jaminan bagi kepastian perlindungan anak. Sebagaimana Arif 
Media Komunikasi dan Informasi Hukum dan Masyarakat

Gosita, mengemukakan bahwa kepastian hukum perlu diusahakan demi kelangsungan kegiatan perlindungan anak dan mencegah penyelewengan yang membawa akibat negatif yang tidak diinginkan dalam pelaksanaan perlindungan anak. ${ }^{1}$

Perlindungan anak dapat dibedakan dalam 2 (dua) bagian yaitu:

a. Perlindungan anak yang bersifat yuridis, yang meliputi: perlindungan dalam bidang hukum publik dan dalam bidang hukum keperdataan.

b. Perlindungan anak yang bersifat non yuridis, meliputi: perlindungan dalam bidang sosial, bidang kesehatan, bidang pendidikan. 8 Pasal 1 angka 2 UU No. 23 Tahun 2002 menentukan bahwa perlindungan anak adalah segala kegiatan untuk menjamin dan melindungi anak dan hak-haknya agar dapat hidup, tumbuh, berkembang, dan berpartisipasi, secara optimal sesuai dengan harkat dan martabat kemanusiaan, serta mendapat perlindungan dari kekerasan dan diskriminasi. $^{2}$

Perlindungan anak dapat juga diartikan sebagai segala upaya yang di tujukan untuk mencegah, rehabilitasi, dan memberdayakan anak yang mengalami tindak perlakuan salah (child abused), eksploitasi, dan penelantaran, agar dapat menjamin kelangsungan hidup dan tumbuh kembang anak secara wajar, baik fisik, mental, dan sosialnya. Arif Gosita berpendapat bahwa perlindungan anak adalah sesuatu usaha

Arief Gosita, 1996, Masalah Korban Kejahatan, PT. Bhuana Ilmu Populer, Jakarta,h.72 melindungi anak dapat melaksanakan hak dan kewajibannya.

Dasar perlindungan anak adalah:

a. Dasar filosofis; Pancasila dasar kegiatan dalam berbagai bidang kehidupan keluarga, bermasyarakat, bernegara, dan berbangsa, serta dasar filosofis plaksanaan perlindungan anak.

b. Dasar Etis; pelaksanaan perlindungan anak harus sesuai dengan etika profesi yang berkaitan, untuk mencegah perilaku menyimpang dalam pelaksanaan perlindungan anak.

c. Dasar Yuridis; pelaksanaan perlindungan anak harus didasarkan pada UUD Tahun 1945 dan berbagai peraturan perundangundangan lainnya yang berlak. Penerapan secara yuridis ini harus secara integrative, yaitu penerapan terpadu menyangkut peraturan perundang-undangan dari berbagai bidang hukum yang berkaitan.

Perlindungan terhadap anak korban kejahatan ( kekerasan ) dapat dilakukan melalui hukum, baik hukum administrasi, perdata, maupun pidana. Kebijakan hukum pidana terhadap perlindungan anak korban dari tindak pidana kekerasan fisik dalam rumah tangga sebagaimana dimaksud dalam pasal 76c, bahwa pelaku kekerasan fisik terhadap anak dipidana dengan pidana penjara paling lama 3 (tiga) tahun 6 (enam) bulan dan/atau denda paling banyak Rp72.000.000,00 (tujuh puluh dua juta rupiah) Penetapan tindak pidana kekerasan pada anak dan upaya penanggulangan kekerasan pada anak dengan hukum, melalui berbagai tahap, sebenarnya terkandung pula upaya perlindungan bagi anak korban kekerasan yang bersifat abstrak atau tidak langsung. Disamping memberikan 
Media Komunikasi dan Informasi Hukum dan Masyarakat

perlindungan secara tidak langsung hukum pidana positif, dalam hal-hal tertentu juga memberikan perlindungan secara langsung. Dalam pasal 14c KUHP ditetapkan bahwa "dalam hal hakim menjatuhkan pidana bersyarat (Pasal 14a), hakim dapat menetapkan syarat khusus bagi terpidana, yaitu " mengganti semua atau sebagian kerugian " yang ditimbulkan oleh perbuatannya dalam waktu yang lebih pendek dar masa percobaannya". Perlindungan yang langsung ini, di samping jarang diterapkan, masih mengandung banyak kelemahan, yaitu:

(1) Ganti kerugian tidak dapat diberikan secara mandiri, artinya bahwa ganti kerugian hanya dapat diberikan apabila hakim menjatuhkan pidana bersyarat;

(2) Pidana bersyarat hanya berkedudukan sebagai pengganti dari pidana pokokyang dijatuhkan hakim yang berupa pidana penjara paling lama satu tahun atau pidana kurungan;

(3) Pemberian ganti kerugian hanya bersifat fakultatif, bukan bersifat imperative. Jadi pemberian ganti kerugian tidak selalu ada, meski hakim menjatuhkan pidana bersyarat.

Menurut Arif Gosita, pelaksanaan perlindungan anak agar nantinya perlindungan anak dapat efektif, nasional positif, bertanggung jawab dan bermanfaat hruslah memenuhi beberapa persyaratan sebagai berikut:

a. Para partisipan dalam terjadinya dan terlaksananya perlindungan anak harus mempunyai pengertian-pengertian yang tepat berkaitan dengan masalah perlindungan anak agar dapat bersikap dan bertindak secara tepat dalam menghadapi dan mengatasi permasalahan yang berkaitan dengan pelaksanaan perlindungan anak. b. Perlindungan anak " harus dilakukan bersama" antara setiap warga Negara, anggota masyarakat secara individual maupun kolektif dan pemerintah demi kepentingan bersama dan kepentingan nasional.

c. Kerjasama dan kordinasi diperlukan dalam melancarkan kegiatan perlindungan anak yang rasional, bertanggung jawab, dan bermanfaat anatara partisipan yang bersangkutan.

d. Perlunya diusahakan invetarisas ${ }^{6} i$ faktor yang menghambat dan mendukung kegiatan perlindungan anak

e. Harus dicegah adanya pemyalah gunaan kekuasan, mencari kesempatan yang menguntungkan dirinya sendirin dalam membuat ketentuan yang mengatur masalah perlindungan anak.

f. Perlindungan anak harus tercermin dan diwujudkan dalam berbagai bidang kehidupan bernegaa dan bermasyarakat.

g. Pelaksanaan kegiatan perlindungan anak, pihak anak harus diberikan kemampuan dan kesempatan untuk ikut serta melindungi diri sendiri dan kelak dikemudian hari dapat menjadi orangtua yang berperan aktif dalam kegiatan perlindungan anak.

h. Pelaksanaan kegiatan perlindungan anak tidak boleh menimbulkan rasa tidak dilindungi pada pihak yang bersangkutan dan oleh karena adanya menimbulkan penderitaan, kerugian pada para partisipan tertentu

i. Perlindungan anak harus didasarkan antara lain atas pengembangan hak dan kewajiban $^{7}$

${ }^{6} \mathrm{lbid}$

${ }^{6}$ Wagiati sutedjo.2006, Hukum Pidana Anak. PT Refika Aditama, januari, Bandung. H.421 Arif Gosita 
Media Komunikasi dan Informasi Hukum dan Masyarakat

\section{KESIMPULAN}

1. Aturan hukum UUPA NO 35 Tahun 2014 memberikan perlindungan anak korban kekerasan fisik dalam rumah tangga sesuai dengan pasal 1 angka 2 tentang kewajiban melindungi hak-hak anak. Dan menjamin hak asasi setiap anak, memberikan sarana dan prasarana serta perlindungan, pemeliharaan dan kesejahteraan anak melalui hak dan kewajiban orangtua.

2. Kebijakan hukum pidana terhadap perlindungan anak korbaan dari tindak pidana kekerasan fisik dalam rumah tangga sebagaimana dimaksud dalam pasal 76c, bahwa pelaku kekerasan fisik terhadap anak dipidana dengan pidana penjara paling lama 3 (tiga) tahun 6 (enam) bulan dan/atau denda paling banyak Rp72.000.000,00 (tujuh puluh dua juta rupiah.

\section{Daftar Pustaka}

${ }^{1}$ Endang Sumiarni, 2003, Perlindungan Hukum Anak Dalam Hukum Pidana, Yogyakarta : Cetakan Pertama, Edisi Pertama, Universitas Atma Jaya, h. 722.

2Departemen Kehakiman Republik Indonesia, 2002, Undang-undang Nomor 23 Tahun 2002 Tentang Perlindungan Anak, Jakarta :Pustaka Yustisia, h. 6

${ }^{3}$ Tim Redaksi Nuansa Aulia, 2009, UndangUndang Dasar 1945 dan Amandemennya, Bandung : Cetakan V, Nuansa Aulia, Pasal 28B ayat (2).

${ }^{4}$ Undang-undang Nomor 35 Tahun 2014 jo Undang-undang Nomor 23 Tahun 2002 Tentang Perlindungan Anak

${ }^{6}$ Waluyadi, 2009, Hukum Perlindungan Anak, Bandung : Cetakan Kesatu, Mandar Maju, 2009, h. 1

7 Endang Sumiarni dan Chandera Halim, 2000, Perlindungan Hukum Terhadap Anak Di
Bidang Kesejahteraan, Cetakan Pertama/Edisi Pertama, Yogyakarta : Universitas Atma Jaya h. 15

8 Undang-Undang Republik Indonesia Nomor 35 Tahun 2014 Tentang Perubahan Atas Undang-Undang Nomor 23 Tahun 2002 Tentang Perlindungan Anak, Pasal 14 ayat (1),

9 Purniaanti, 1996, Apa dan Bagaimana Kekerasan Dalam Keluarga, Jakarta : Kongres Wanita Indonesia (KOWANI).

${ }^{10}$ Taylor, Shelley E., Peplau Leitia Anne \& Sears, 2009, Psikologi Sosial, Jakarta : Edisi 12, Kencana, 2009, h. 24

Undang-undang No 35 Tahun 2014 Tentang Perubahan Atas Undang-Undang Nomor 23 Tahun 2002 Tentang Perlindungan Anak,

2 UUPA Nomor 35 Tahun 2014 pasal 1, 76 E dan pasal 82

Redaksi, 2000, Sinar Grafika, Undang-Undang Peradilan Anak, Jakarta : Sinar Grafika

Arief Gosita, 1996, Masalah Korban Kejahatan, PT. Bhuana Ilmu Populer, Jakarta,h.72

Abdul Hakim G. 1996, Nusantara, Hukum dan hak-hak anak, Prospek Perlindungan Anak, CV. Rajawali, Jakarta,h.104

Moerti Hadiati Soeroso, 2010, Kekerasan Dalam Rumah Tangga Dalam Persepektif Yuridis Viktimologis, Jakarta : Sinar Grafika,. h.1

Dirjosisworo, S.,2005, Sosio kriminologi Amalan IImu-IImu Sosial Dalam Studi Kejahatan, Bandung, Sinar Baru, h.87 